\title{
NGOS AND THE HOMELESSNESS IN KUALA LUMPUR: TOWARDS MORALISTIC TRUST
}

\author{
Prescious Ann Santos Oria, Nobaya Ahmad \& Hanina Halimatusaadiah Hamsan \\ Department of Social \& Development Sciences, \\ Faculty of Human Ecology, \\ Universiti Putra Malaysia \\ (xiouz_faith@yahoo.com,nobaya@upm.edu.my, hanina@putra.upm.edu.my)
}

\begin{abstract}
The aim of the paper is to provide a descriptive analysis of the role of NGOs that provide food distribution to the homeless in Kuala Lumpur. Using personal interviewing as a method of data collection, the study focuses on the aspect of social capital amongst the Non-Governmental Organizations, especially in terms of bonding and bridging social capital. Analysis of the data procured from the NGOs was done, and trust as one of the components of social capital is seen evidently in the study. This paper defines a new kind of trust that exists between the seven NGOs and the homeless people in this particular context, namely moralistic trust. Informants who have been interviewed all declared a uniform insight towards their relationships to the homeless, giving us a new understanding as to how NGOs build trust with those who are considered destitute, weak, doomed, losers or marginalized in society.
\end{abstract}

Keywords: NGOs, homeless, trust, moralistic trust, social capital

\section{Homelessness}

Homelessness is a word that is commonly associated to Social problem as it is inevitably faced by all societies over the years. Many social scientists have embarked their works focusing on the various facets of homelessness as it impacts the social, economic, political aspect of a particular community.

It is regarded as a widespread illness in social context for its presence affects both rural and urban areas, debunking the early idea that homelessness is only prevalent in rural areas where poverty is most rampant. Consequently, the concept of homelessness has evolved over the years. In general terms, these 
homeless are typically defined as people who dwell on the streets, alleys, improvised shelters, under bridges or other public places, abandoned buildings and even living with friends and relatives which complicates the accurate figure of the homeless population in particular community (Timmer, Eitzen, \& Talley, 1994, p. 12). The common notion about homeless as beggars, psychotics, lazy people, substance-abusive, alcoholics, criminals and the like even changed throughout time as people become more inclined in studying these homeless folks. Even wider and deeper understandings about why homelessness takes place in many communities were dug by social scientists, and that having a more advanced context is not an assurance of the absence of homelessness. It is evident in literatures that not only the underdeveloped and developing countries do have homeless cases. It is also evident in the developed countries. UN reported that even countries with high income experience homelessness because of rapid urbanization and structural changes in the society (Levinson \& Ross, 2007, pp. 374-375). With all the industrialization happening in the city centres, an inflation rate occurs on the number of migrant people coming from rural areas in urban region due to better and wider work opportunities. While all of these people have strong expectations that they will escape poverty by chasing their good lucks in the city, some of them end up hopeless to the extent of becoming homeless. Moreover, it is seen that because of urbanization, cost of living becomes higher and higher that even the city dwellers find it hard to rent housing and pay other amenities for their survival (Gerdes, 2005, pp. 21-29).

In the United States, the National Student Campaign against Hunger and Homelessness (NSCAHH) stated that homelessness and hunger increase in number nationwide. This shows that even a rich country is not excluded in experiencing homelessness. Despite of the problem, USA made measures to combat the issue. It has been said that for the past 25 years, America has came up of emergency food and shelter providers that responded to the basic needs of the people. It was the time soup kitchens, pantries and shelters started to set off, which has resulted to the active participation of charitable agencies in service provision. Because most people seek their assistance, those agencies grew more in number. At present, developed countries display various interventions executed both by the government and the Non-Government sectors.

Furthermore, for developing countries, it is seen that intervention done are seemingly limited and even unhelpful sometimes. In the study done in South East Asia, advocacy for homelessness in the case of India, Bangladesh and Peru has been focused to homeless affected by natural calamities such as flooding and earthquakes. There are also policy-related interventions but are just partial in scope. (Tipple \& Speak, n.d.; Speak, 2004, p. 477) 


\section{Homelessness in Malaysia}

In Malaysia, it has been said that there are around 1,400 homeless people residing in Kuala Lumpur area based from the 2010 survey done by the Ministry of Women, Family, and Community Development (MWFCD). These are people coming from different walks of life - different places of origin, ethnic groups, gender, ages, religions, aptitudes, family backgrounds and with different life stories (Ruseko Shimizu, 2014, p. 3). Even the Organizations working for the homeless' welfare in Kuala Lumpur have reported a rough estimate of 1200 or more for the homeless statistics, hence, execution for a survey research is required to be able to provide a more accurate and updated data not just for the government or institutions and organizations working for the homeless but for the public as a whole. Nevertheless, some other organizations are never concerned about having homeless' data at all, some organizations have been concerned about the profile and number of the homeless whom they are providing services, and thus they maintain a database to monitor their organizational outcomes. With this, they are aware that some of the homeless originate outside Kuala Lumpur and Selangor state; they come from different states of Malaysia as far as Johor Bahru in the South, Kelantan in the North-east and Sarawak in the East of Peninsular Malaysia. Based from the participant observations done, it was observed that homeless people come from different age brackets: most are young adults around 25-40 years old and some old-aged people around 50 years old above. It is also evident that men outnumber women regardless of the race they come from whether they are Malay, Chinese, Indian or even non-Malaysians such as Bangladeshi and Indonesians. Each of the homeless has different personal stories to tell as to why they end up becoming homeless and these include marriage breakdown for old people, joblessness, family problems, taken advantaged by other people and even family persecution (J. Cheah, personal communication, February 18, 2014). While majority of this population do not have work, some of them work into small-scaled jobs paid with a meagre salary which pushes them to choose living on the street rather than renting an inn. Some of them even own gadget such as phone and mp3 players which according to one of the NGO project directors, "the only treasure they may have". Thus, homeless definition in Malaysian context is not contained or limited to the common misconceptions of people - them as the drug addicts, psychotics, lazy people, dirty ones, jobless, penniless, savage and the like. And this is what NGOs wanted to be changed amongst people's way of thinking, to at least better understand the real condition of the homeless.

Meanwhile, Alhabshi \& Manan (2012, p. 1) argued that homeless people receive not a large amount of attention because there is no clear policy under the Ministry of Women, Family and Community Development that has direct bearing 
to the issue of homelessness. But in early 2000, homeless began to receive an evident focus when Non-Governmental Organizations in the city which includes charitable and religious organizations started to make a step in assisting the homeless specifically on food provision (Rusenko Shimizu, 2014, pp. 2-3). Through the consistent and active advocacies of these NGOs and with the increasing issues on homelessness, the Government also took action by building Anjung Singgah, a transitional home under the initiative of MWFCD and currently managed by the Yayasan Kebajikan Malaysia (YKN) or the National Welfare Foundation Malaysia. Designed to cater the primary needs of the homeless people, Anjung Singgah serves as a temporary shelter for the homeless over a period of two (2) weeks before they get reintegrated in the society. With the help of the volunteers, homeless are provided with various services such as counselling, food, clothing, medical aids, and job supports through referrals aside from dwelling in the shelter. Currently, Anjung Singgah is the sole centre in Kuala Lumpur chiefly designed for the homeless populace as a transit or shelter home which is recognized by the Government. However, there may be other shelter or transit homes managed by private organizations.

In spite of the idea that the Government has put up this transitional housing as a step in highlighting and addressing the needs of this particular sector in the community, Malaysian Non-Governmental Organizations never cease to play their part in meeting the needs of the growing homeless population. In fact, these NGOs are in a constant pursuit of developing and expanding possible services which they could offer to the homeless. Azman \& Sulaiman (2011, p. 53) said that efforts by these many NGOs are offered to complement the programmes of the government for the urban poor.

\section{NGO that Provide Food Support to the Homeless in KL}

In Kuala Lumpur, a number of Non-Governmental Organizations that provide food support to the homeless have been actively pursuing their advocacy since early 2000. According to Yayasan Kebajikan Negara (YKN) or the National Welfare Malaysia, at present, there is no existing official record of the NGOs undertaking this advocacy, nevertheless for the previous years, the active engagement of Malaysian NGOs in combating homelessness in the country has been apparent to the public as they persistently give away food packs to the homeless in Kuala Lumpur area. And up to the present, their advocacy continues to build up as their awareness escalates that the issue of homelessness becomes more and more complex nowadays due to the increasing number of their homeless clients on a regular food distribution. 
In a research done on the Social Capital amongst NGOs who provide food support to the homeless in Kuala Lumpur, seven (7) NGOs were explored through in-depth interviews with project heads and managers of the organizations. The NGOs were chosen based from their availability and response during the data collection period. For the background of the NGOs subject under the study, the table below shows the Project Launching Year, Number of days of Food Distribution per Week, as well as the number of Food Packs distributed per week.

Table 1. NGOs Profile

\begin{tabular}{|c|c|c|c|}
\hline NGO & $\begin{array}{c}\text { Project Launching } \\
\text { Year }\end{array}$ & $\begin{array}{c}\text { Number of days of } \\
\text { Food distribution } \\
\text { per Week }\end{array}$ & $\begin{array}{c}\text { Number of Food } \\
\text { Packs distributed } \\
\text { per Week }\end{array}$ \\
\hline 1 & 2001 & 4 & 1,230 \\
\hline 2 & 2005 & 6 & 4,600 \\
\hline 3 & 2007 & 3 & 450 \\
\hline 4 & 2009 & 1 & 250 \\
\hline 5 & 2007 & 1 & 130 \\
\hline 6 & 2006 & 7 & 2,500 \\
\hline 7 & 2010 & 4 & 2,550 \\
\hline
\end{tabular}

Based on the information gathered from the informants under the 7 NGOs, it was observed that each organization's day and time schedule on food distribution in Kuala Lumpur does not overlap with other NGOs. From the above data, it is also apparent that the number of days where NGOs distribute food varies. Some distribute once a week only while others do it thrice or even daily. Along with the differences on schedule, they also have different areas of distribution which make them more fixed and focused. In spite of not having formal communication amongst these NGOs, each of them is aware about the schedule and places of distribution of the other organizations. By saying this, they believe that there is no sense of competition amongst them but they do complement one another instead. Majority of them believe or have faith on the advocacy of one another and that each of them has the capability to make a change to the homeless. Some of the informants even clearly stated that they do not distribute food on a daily basis because they trust that there are other NGOs who are doing the same thing as them, and that in times they don't distribute food, they are confident that other NGOs will do it for them. This shows an element of trust amongst these organizations even if there is no close contact amongst them. 
Moreover, These 7 NGOs, though they have different vision statements, still share the same meaning on their advocacy. All of them focus on helping the homeless, needy, underprivileged, poor \& distressed people by supporting and providing them the most basic thing they need: food. Being in the frontline, these NGOs' direct contact to the homeless make them understand that while food is the most immediate need of the homeless, it is not the only thing they need. They are also human beings who have holistic needs for survival. Thus, apart from food provision, NGOs also offer extra services covering their physical, mental, emotional and social needs such as medical assistance, counselling, assistance on homeless' ICs registration or replacement, registering old people for monthly allowance from the Government, referral to other NGOs, Homes, Rehabilitation Centres and other organizations that could cater the right assistance they need, free haircut, reunification of families through provision of transportation tickets to deserving homeless, free laundry and bathing, movie nights, and other more that has positive impact to the homeless' welfare. While the organizations are more individualistic in executing their advocacy for the homeless, a pattern of similarity on the nature of services they provide is evident amongst them all. In his study about the homeless movements in Japan, Hasegawa (2006, pp. 11-12) has concluded three reasons why there's a similarity of programmes provided by different groups for the homeless population. First, it is due to the fact that groups working for the homeless may have better chances to exchange and learn ideas from one another since Japan has fewer number of homeless as compared to other countries; Second, because these groups have gained ideas from organizational media, newspapers and other media-mediated tools for information dissemination; and third, because groups believe that the programmes they have are the essential needs that would address the topmost problems existing in the community. As for the NGOs in Malaysia, it is seen that the conclusion of Hasegawa is also applicable except that Malaysian NGOs working for the homeless do not formally and purposely communicate to one another making the learning or exchange of ideas less emphasized.

\section{Trust between the NGOs and the Homeless}

Given that the focus of the research study is on Social Capital, trust is one of the main considerations in understanding the existing social capital amongst the organization. While the study is mainly focused on the relationship of the NGOs giving food support to the homeless people, one of the interesting issues that came up in the research is the relationship between the NGOs and the homeless, particularly on the kind of trust that exists between them. 
Works on literatures state that trust is an element of Social Capital and has been regarded by social scientists as one of the main ingredients of social capital. Researchers say that the presence of trust is an inevitable component which is useful in determining the existence of social capital in any given community of interest (Morrone, Tontoranelli \& Ranuzzi, 2009, p. 8). In Community Development, trust is seen as a public good that is important to individuals, groups and communities as a whole (Stolle, 2002, p. 397) for it serves as lubricant or glue that makes society more cohesive one and also civic work united (Arneil, 2006 , p. 4) suffice to say that trust doesn't only serve the private goals of an individual but also serve the goal of groups or communities towards civic works. In addition to this, trust provides a sense of security to people as they become aware that provisions are available for them. Might as well, trust drives people to take more risk and become more vulnerable to various possibilities (Ward \& Smith, 2003, p. 1). In addition, in their book entitled "In Good Company", Cohen \& Prusak (2001, pp. 28-29) restated John Locke's account about the importance of trust to human society. Trust is a basic need of human that he has compared it to the air that we breathe. Thus without a certain amount of it, there would be no relationship that would lead people to connections and cooperation towards a developed community. Having no trust means "isolated individualism".

Furthermore, talking about Social Capital, trust is also commonly associated to thick-trust or the particularized trust and thin-trust or the generalized trust. It has been said that particularized trust is more evident in homogenous groups where members are bonded together. People who encompass this kind of trust easily trust people who are like them or the people in the same group as them. There is a strong tie amongst them built from their in-group interaction over time. Writers say that because of particularized trust, people sometimes become limited to the point of leaving no room of trusting people outside their group. On the other fence, generalized trust exists on heterogeneous groups where people easily trust people who are like them as well as people who are unlikely them or people outside their group. This kind of trust is common to people who are inclined to civic works (Uslaner, 2008, p. 104).

Generally, trust is considered to be a multidimensional concept that exists through people belonging to families, groups of different kind, organizations, and even to institutions (Morrone, Tontoranelli \& Ranuzzi, 2009, p. 5). Normally, in a society, trust is more evident among people who are of equal status or it is easier for people to trust the "normal" ones like them, those who have educational attainment, working people, but not with those who are considered and perceived deviants or vulnerable like the criminals, prisoners, beggars or even the homeless for they are seen as lesser trustworthy as compared to the other bracket of the population. Marginalized as they are, one would think twice when to consider 
giving them trust for it is easier to give trust to people whom we can identify ourselves with than to people whom we cannot (Stolle, 2002, pp. 401-402).

Going back to the idea that diversity of ethnic groups in Malaysia is enormous due to the three major ethnicities namely the Malays (62.3\%) which consist majority of the population, the Chinese $(22 \%)$, Indians $(6.7 \%)$, other races $(0.9 \%)$ and non-citizens $(8.1 \%)$ which is according to the Department of Statistics Malaysia, it is then very essential for these NGOs to consider all the homeless' culture and religion in choosing the kind of food they serve. All of the 7 NGOs showed their strict observance on the quality of food with the goal that it would be able to cater everyone regardless of the ethnic groups where they come from. It is important to highlight that majority of the NGOs are being run by religious organizations, yet their advocacy is inclusive and impartial, that is to say that homeless are being reached out regardless of their religious and ethnic backgrounds, gender and age, physical and mental conditions. Homeless are well treated because NGOs believe that they are also individuals who have needs like majority of us, and because they are human beings, they also have moral values. This is the very reason as to why the Non-Governmental Organizations under the study put so much strength and passion in executing their advocacies. Informants even disclosed that as much as possible, food being served should be as delicious as the food they eat at home. They also ensure that there's a variety of menu because even the homeless know how to get bored with the same kind of food daily. Generally, all of the NGOs declared that chicken is the safest viand for it is consumed largely by the homeless while some others also include fish. They make sure that it is pork-free as it is haram or not taken by the Malays and beef-free as it is not taken by Indians and some Chinese. Vegetarian food is also served most of the time together with rice, noodles, bottled water, teh tarik (milk tea) or cold drinks, some fruits plus other treats such as biscuits and bread. With this, NGOs strongly believe that homeless will take and consume what they serve. All of them were confident to say that the homeless trust them so much because they are aware that the food they prepare doesn't harm them.

The way NGOs serve food differs as well. Most of the NGOs serve in plates while some others serve in packet. For those who serve in plates also provide tables and chairs to the homeless because for them, these represent honour and dignity to them. One of the NGOs doesn't even ask the homeless people to queue in a line to get their food. Instead, they ask them to just have seats and the volunteers will hand them food and drinks on their respective tables. Informants said that even they are homeless they still deserve the best treat from them. Also, NGOs are not concerned about the issue of overfeeding. Majority of them said that they allow the homeless people take extra food for the second time. Some of them even said that they can take extra food even to the n-times as long as 
they will consume it. They trust the homeless that when they take food, they will be able to finish it and that giving them extra is also like giving them extra points.

In this scenario, one would say that homeless are being respected by the NGOs not just on the quality of food they distribute per se but also on the way they provide their services, suffice to say that Malaysian NGOs trust to the homeless is not based on religious or ethnic trust. They go beyond the idea of just providing food but they also take into consideration the type of food that is reasonable for these homeless. And they do not just stop in there, because they even go beyond the quality of food. They make sure that their ways of feeding the homeless should always highlight the homeless' moral value, and that is to say that even if they are perceived homeless, they have the right to have the best. Dignity and morality are the greatest things they can give to the homeless, thus, they offer the best that they can do to them ranging from quantity to quality of services up to the way they relate to these so called "clients". Different from the trust that exists within homogenous groups or the particularized trust like family trust, religious trust or organizational trust, the kind of trust that works between the NGOs and the homeless is moralistic trust as coined by Uslaner. For two different groups coming from different milieus, the "powerful" or the NGOs in this case as they are the dominant and the "vulnerable" or the homeless, to have trust to each other, an understanding about the goodwill of each other should be present. This is what Uslaner meant when he said that people treat each other as if they are trustworthy. A kind of trust that neither strategic/knowledge-based nor specific but with a general thinking that people should treat others the way they want to be treated back (Uslaner, 2008, p. 103). He is right in saying that moralistic trust is needed when engaging to civic works. It's a trust in humanity.

Highlighting the homeless on the other hand, in response to the trust that NGOs offer to them, they become more confident that these organizations would always provide them food which gives them a sense of security. Project heads said that most of the homeless became regular clients to their organizations. Also, trust of the homeless towards the NGOs are not seen or reflected only on their everyday or regular attendance on food distributions but also on their relationship to volunteers of the organizations as they open up their personal issues to them. In the participant observations done, it was noticed that some of the homeless have been closed to the regular volunteers that they even update them about their recent experiences, needs and other personal issues.

\section{Conclusion}

The role of NGOs is not only limited on giving food and providing extra services to the homeless population but extends to a kind of relationship that impacts to the homeless. One can say that when homeless people, who are seen as destitute, 
doomed or losers are trusted by the Non-Governmental Organizations who provide food, a trust from the homeless is also given in return to the organizations. Homeless are given hope and sense of security that make them not worry about the food they will eat knowing that NGOs are fully aware about the homeless - the type of food they eat, the other services they need, the way they should be served and the like. Therefore, this trust existing between these two groups is neither a family trust nor religious trust nor organizational kind of trust but a moralistic trust because they believe on the same moral principle. Moreover, the existence of a moralistic kind of trust between theses NGOs and the homeless in Kuala Lumpur builds a more positive outlook on how groups and organizations should cater services to the needy people by considering their backgrounds as human and not just for the sake of meeting organizational goals for the public to see. After all, the most important thing at the end of the day is the trust given out to people specially to those marginalized and weak.

\section{References}

Alhabshi, S. M., \& Abdul Manan, A. K. (2012). Homelessness in Kuala Lumpur, Malaysia: A case of agenda denial. International Journal of Social Science Tomorrow, 1(2), 1-9.

Arneil, B. (2006). Diverse communities. Cambridge: Cambridge University Press.

Azman, A., \& Sulaiman, J. (2011). Urban poverty: The invisible poor population in Malaysia. Asian Social Work Journal, 1(1), 43-62.

Cohen, D., \& Prusak, L. (2001). In good company. USA: Harvard Business School Press.

Hasegawa, M. (2006). "We are not garbage!" The homeless movement in Tokyo, 19942002. New York, USA: Routledge.

Levinson, D., \& Ross, M. (2007). Homelessness handbook. USA: Berkshire Publishing Group.

Morrone, A., Tontoranelli, N., \& Ranuzzi, G. (2009). How good is trust: Measuring trust and its role for the progress of societies. Organization for Economic CoOperation and Development (OECD) Statistics Working Paper. STD/DOC (2009), 3.

National Student Campaign against Hunger \& Homelessness. (2005). "Homelessness as a widespread problem", in L. Gerdes (Ed), The Homeless. USA: Greenhaven Press, 21-29.

Ruseko Shimizu, R., (2014). "The Anjung Singgah Strategy: Simultaneous Inclusion and Exclusion of Homelessness in Malaysia's Policy Agenda". Paper presented at the Annual meeting of the American Sociological Association Annual Meeting, Hilton New York and Sheraton New York, New York, 
NYOnline. Retrieved from, http://citation.allacademic.com/meta/p650183 _index.htm

Speak, S. (2004). Degrees of destitution: A typology of homelessness in developing countries. Housing Studies, 19(3), 465-482.

Stolle, D. (2002). Trusting strangers - The concept of generalized trust in perspective. Österreichische Zeitschrift für Politikwissenschaft, 31, 397-412.

Timmer, D. A., Eitzen, D. S., \& Talley, K. D. (1994). Paths to homelessness extreme poverty and the urban housing crisis. USA: Westview Press.

Tipple, G., \& Speak, S. (n.d.). The relationship between economic development and homelessness in South East Asia.

Uslaner, E. (2006). Trust and economic growth in the knowledge society. Lecture at the Osaka University, March 7-9, Japan. (2008). "Trust as a moral value", in D. Castiglione, J. Van Deth, \& G. Wolleb (Eds), The handbook of social capital. UK: Oxford University Press, 101-121.

Visit Malaysia 2014. (2014). Fast facts. Retrieved from, www.vmy2014.com/aboutvmy2014/fast-facts.

Ward, A., \& Smith, J. (2003). Trust and mistrust: Radical risk strategies in business relationships. UK: Wiley. 